\title{
Genetic Diversity of Microbial Eukaryotes in the Pelagic and Littoral Zones of Lake Taihu, China
}

\author{
Biying Zhao ${ }^{1, *}$ and Feizhou Chen ${ }^{2}$ \\ ${ }^{1}$ International Genome Center, Jiangsu University, Zhenjiang 212013, China \\ ${ }^{2}$ State Key Laboratory of Lake Science and Environment, Nanjing Institute of Geography and Limnology, Chinese Academy of Sciences, \\ Nanjing 210008, China
}

\begin{abstract}
Genetic diversity of microbial eukaryotes $(0.8-20 \mu \mathrm{m})$ and its seasonal variation in the pelagic and littoral zones were investigated from in Meiliang Bay of Lake Taihu in China. The water samples were collected in four seasons (February, May, August, and November). The genetic diversity of microbial eukaryote was analyzed by terminal restriction fragment length polymorphism (T-RFLP) of PCR-amplified partial eukaryotic 18S rRNA fragments. T-RFLP indicated that the microbial eukaryotic community compositions differed between the pelagic and littoral zone, but the difference decreased in warm seasons. The main environmental factors which affected on the variations of microbial eukaryotic community compositions in pelagic and littoral zones were revealed by multivariate statistical analysis. The canonical correspondence analysis between the genetic diversity of microbial eukaryotes and environmental factors revealed the trophic status had the most important impact on the microbial eukaryotic communities. Besides, a strong top-down regulation of microbial eukaryotes by zooplanktons was found in summer.
\end{abstract}

\section{Introduction}

The microbial eukaryotes $(0.8 \sim 20 \mu \mathrm{m})$ which mainly consist of small algae (primary producers) and protozoa (consumers) are the fundamental components of the microbial food web [1]. Algaes and protozoa play a vital role in global mineral, carbon cycles, global silica, and climate regulation [2-4]. Normally, most microbial eukaryote assemblages, such as algae, are susceptible to environmental deterioration and pollution. Therefore, these microorganisms could be used as biomonitors for assessing aquatic ecosystem due to their sensitivity to environmental deterioration and pollutants $[5,6]$. As predators, producers, decomposer and parasites, the microbial eukaryotes play key roles in the ecological functioning and process of biological ecosystems [7]. Therefore, it is important to study the genetic diversity of microbial eukaryotes to characterize both biogeochemical processes and aquatic ecosystem health.

As large phytoplankton and zooplankton could be identified by microscope, small algae and protozoa are difficult to distinguish. Fortunately, molecular methods are used to investigate microbial eukaryotes, and widen our knowledge of microbial eukaryotic community compositions in aquatic ecosystems $[8,9]$. Changes in microbial eukaryotic community composition from the pelagic and littoral zones in different seasons were assessed by terminal restriction fragment length polymorphism (T-RFLP).

A few studies have been made to relate the structure of microbial eukaryotic communities with biological, chemical, and physical variables in a lake [2, 10-15]. Some studies have reported seasonal changes in microbial eukaryotic community structure [16] in relation to environmental variables, such as grazing (top down) and resources (bottom up).

Lake Taihu - the third largest lake of China, is a shallow subtropical lake. And Meiliang Bay located at north of Lake Taihu represents a phytoplankton-dominated habitat and is one of the most eutrophic regions in Lake Taihu due to its high cyanobacterial density [17]. There were a few studies of microbial eukaryotes in Lake Taihu $[10,16,18]$, but very few data on genetic diversity of microbial eukaryotes from the pelagic to littoral zone in this freshwater lake was reported. The region in a lake that is neither close to the bottom nor near the shore could be defined as the pelagic zone, while the littoral zone is the part of a lake that is close to the shore.

In this study, T-RFLP analysis was performed to analyze the variation of diversities of microbial eukaryotes from the pelagic and littoral zones in Lake Taihu. The objectives of our study were to determine (i) the genetic diversities of microbial eukaryotes in the pelagic and littoral zones; (ii) the relationship between the compositions of the microbial eukaryotic community and the environmental factors.

\section{Methods and materials}

\subsection{Study sites and sampling}

\footnotetext{
* Corresponding author: zhaoby@ujs.edu.cn
} 
Meiliang Bay which located in the north of Lake Taihu covers an area of about $100 \mathrm{~km}^{2}$, and it is one of the most eutrophic regions in Taihu Lake. Samples were collected from the pelagic zone to littoral zone in Meiliang Bay of Lake Taihu in February, May, August and November, 2008: the distances from shore were $3 \mathrm{~km}, 2 \mathrm{~km}, 1 \mathrm{~km}$, $500 \mathrm{~m}, 250 \mathrm{~m}, 100 \mathrm{~m}, 50 \mathrm{~m}, 25 \mathrm{~m}, 20 \mathrm{~m}, 10 \mathrm{~m}, 5 \mathrm{~m}, 2 \mathrm{~m}$, respectively, and were numbered 1-12 consecutively. So the samples collected in February were marked TF1-TF12, in May were named TM1-TM12, in August were named TA1-TA12, in November were named TN1-TN12 in this study. According to the depth of water and the distances from sampling sites to shoreside, the 12 samples sites were divides into two parts: 1-6 belonged to the pelagic zone and 7-12 belonged to the littoral zone. So the samples in February from TF1 to TF6 were named FebP, and from TF7 to TF12 were named FebL, such as the samples in the other seasons (MayP and MayL, AugP and AugL, NovP and NovL).

Water samples for abiotic and biotic parameters detection were collected. The microbial eukaryote samples were obtained by $200 \mathrm{~mL}$ lake water from the initial water samples collected on $0.8-\mu \mathrm{m}$-pore-size polycarbonate filters (Millipore) at a pressure $<10 \mathrm{kPa}$ after the $20-\mu \mathrm{m}$-pore-size mesh prefiltered. Filters were stored at $-80{ }^{\circ} \mathrm{C}$ until nucleic acids were extracted.

All the abiotic and biotic factors were measured according to standard methods[19].

\subsection{T-RFLP}

DNA was extracted using a combination of hot detergent lysis buffer and mechanical disruption [20]. The 18S rRNA genes were amplified using eukaryote-specific primers, Ek-1F-CY5 (5'- CTGGTTGATCCTGCCAG-3') and Ek-516r (5'-ACCAGACTTGCCCTCC-3')[14, 21], and approximately 560-base pairs (bp) fragment was amplified.

Three to four replicate PCR products were purified and concentrated into a single $50-\mu \mathrm{L}$ aliquot using the E.Z.N.A. ${ }^{\mathrm{TM}}$ Cycle-Pure Kit (Omega). Purified and concentrated T-RFLP products were digested with 10U of mung bean nuclease (TaKaRa) to remove any partially single-stranded amplicons that might confound T-RFLP analysis [22]. Mung bean digests were cleaned and purified by the E.Z.N.A. ${ }^{\mathrm{TM}}$ Cycle-Pure Kit, and then 200 ng of PCR product was enzymatic digested by incubating with $20 \mathrm{U}$ of $M s p$ I at $37^{\circ} \mathrm{C}$ for $2 \mathrm{~h}$. The digestion products were purified again. The terminal restriction fragments (T-RFs) were separated by a CEQTM 8000 capillary-based DNA sequencer (Beckman Coulter) following general guidelines for T-RFLP. Results were analyzed by the Fragment Analysis module of the CEQTM 8000 GENETIC ANALYSIS software by a $5 \%$ threshold. We considered fragments from different profiles having $<1 \mathrm{bp}$ difference to be of the same length to account for small differences in running time among samples. Results were expressed as a percentage of the total area.

\subsection{Statistical analysis}

The relationships between the microbial eukaryotic community composition based on T-RFLP and the environmental parameters were revealed by canonical correspondence analysis (CCA) (if the length of the first detrended correspondence analysis axis (DCA) run on species data was $>2$ ). The environmental parameters included abiotic and biotic factors, and all data were $\log (\mathrm{x}+1)$ transformed [23]. The environmental factors that best described the most influential gradients in community composition were identified by forward selection with 499 unrestricted Monte Carlo permutations. CCA was performed with the software CANOCO 5.0 for Windows ( Microcomputer Power )

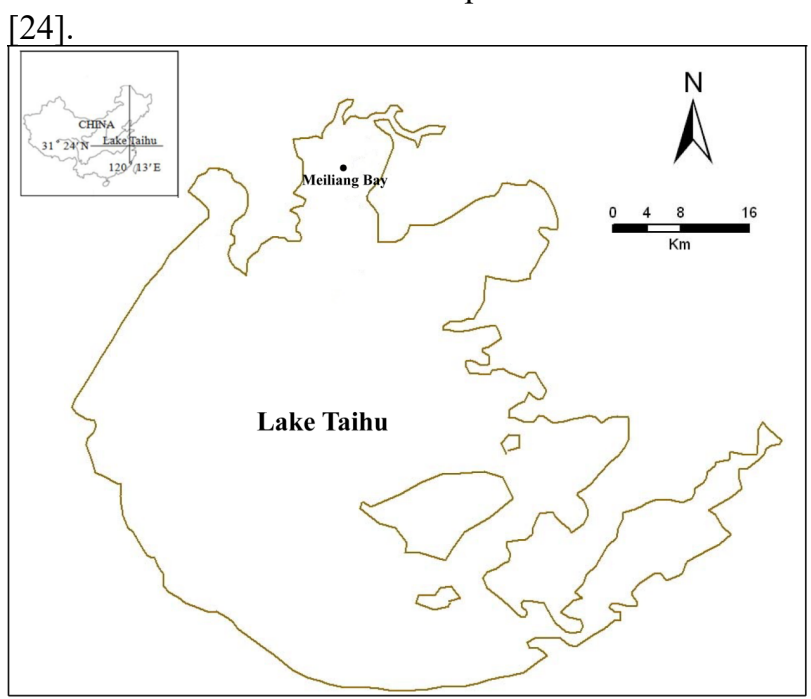

Fig. 1. Sampling location $(\bullet)$ was located at Lake Taihu, China.

\section{Results}

\subsection{Physicochemical and Biological characteristics of the sampling sites}

The physicochemical and biological characteristics of the samples from the pelagic and the littoral zone in four seasons were quite different (Table 1). Two-Way ANOVA showed that $\mathrm{SD}, \mathrm{DO}$ and $\mathrm{pH}$ declined gradually with the decreases of distances between sampling sites and shoreside $(p<0.05)$, while TSS and phytoplankton biomass increased significantly $(p<0.05)$ during the whole year. Besides, the temperature, $\mathrm{pH}$, the concentration of chlorophyll $a(\mathrm{Chl} a)$ and Copepoda abundance displayed similar seasonal changes: their values increased from February to November with peaks in August, and then decreased in November $(p<0.05)$. The highest values of $\mathrm{NO}_{\mathrm{x}}^{-}-\mathrm{N}$ concentration and Cladocera density were found in May, and then decreased over time $(p<0.01)$. The DO and TN values decreased firstly and then increased, with their lowest values appearing in May $(p<0.01)$. $\mathrm{PO}_{4}{ }^{3-}-\mathrm{P}$ concentration fluctuated, with its lowest value appearing in May and highest value in August $(p<0.01)$. Both rotifrea abundance and zooplankton biomass were maximum in February and then decreased over time $(p<0.01)$. 
Table 1. Physical, chemical and biological factors of the study sites in Meiliang Bay of Lake Taihu, China. The 12 samples sites were divides into two parts: 1-6 were assigned to the pelagic zone and 7-12 to Based on this, for February, the samples marked with TF1-TF6 were named FebP, while the samples with the littoral zone. TF7-TF12 were named FebL. Similarly, the samples collected in the other seasons were named MayP and MayL for May, AugP and AugL for Auguest, NovP and NovL for November, respectively.

\begin{tabular}{|c|c|c|c|c|c|c|c|c|}
\hline & ebP & FebL & MayP & MayL & AugP & AugL & NovP & NovL \\
\hline Depth (m) & $2.03 \pm 0.23$ & $\begin{array}{c}0.75 \quad \pm \\
0.39\end{array}$ & $\begin{array}{c}2.13{ }^{ \pm} \\
0.23\end{array}$ & $\begin{array}{c}0.85{ }^{ \pm} \\
0.39\end{array}$ & $2.43 \pm 0.23$ & $\begin{array}{c}1.15 \pm \\
0.39\end{array}$ & $2.33 \pm 0.23$ & $1.05 \pm 0.39$ \\
\hline $\begin{array}{c}\text { Temperature } \\
\left({ }^{\circ} \mathrm{C}\right)\end{array}$ & $\begin{array}{c}10.33 \pm \\
0.26\end{array}$ & $\begin{array}{c}10.02 \pm \\
0.41\end{array}$ & $\begin{array}{c}25.93 \pm \\
0.24\end{array}$ & $26.20 \pm 0$ & $\begin{array}{c}30.33 \pm \\
0.14\end{array}$ & $\begin{array}{c}30.48 \pm \\
0.08\end{array}$ & $16.22 \pm 0.26$ & $\begin{array}{c}16.97 \pm \\
0.08\end{array}$ \\
\hline $\mathrm{SD}(\mathrm{cm})$ & $\begin{array}{c}46.67 \pm \\
7.53\end{array}$ & $\begin{array}{c}30.83 \pm \\
11.58\end{array}$ & $\begin{array}{c}34.50 \pm \\
4.93\end{array}$ & $\begin{array}{c}35.50 \pm \\
8.80\end{array}$ & $\begin{array}{c}31.17 \pm \\
5.91\end{array}$ & $\begin{array}{c}28.33 \pm \\
14.11\end{array}$ & $42.33 \pm 8.33$ & $\begin{array}{c}20.00 \pm \\
5.48\end{array}$ \\
\hline $\mathrm{pH}$ & $7.54 \pm 0.07$ & $7.70 \pm 0.03$ & $8.74 \pm 0.11$ & $8.15 \pm 0.37$ & $9.01 \pm 0.40$ & $8.25 \pm 0.24$ & $8.48 \pm 0.08$ & $8.26 \pm 029$ \\
\hline $\mathrm{DO}(\mathrm{m}$ & $.59 \pm 0.67$ & $7.71 \pm 0.42$ & $5.39 \pm 0.98$ & $3.09 \pm 1.01$ & $6.63 \pm 0$ & $2.70 \pm 1.63$ & $10.13 \pm 0.41$ & $9.43 \pm 1.44$ \\
\hline $\mathrm{TN}($ & $5.40 \pm 0.32$ & $20 \pm 0.05$ & $1.84 \pm 0.42$ & $2.23 \pm 0.62$ & $1.97 \pm 0.49$ & $2.36 \pm 0.40$ & $2.09 \pm 0$ & 1.22 \\
\hline $\mathrm{NH}_{4}{ }^{+}-\mathrm{N}(\mathrm{mg} / \mathrm{L})$ & 0 & $8 \pm 0.02$ & $0.01 \pm 0$ & $0.15 \pm 0.17$ & $0.42 \pm$ & $0.36 \pm 0.02$ & $0.22 \pm$ & \\
\hline & & $94 \pm 0.94$ & $1.19 \pm 0.07$ & $1.02 \pm 0.13$ & & $0.62 \pm 0.01$ & $0.40 \pm 0.12$ & $0.37 \pm 0.08$ \\
\hline & & $4 \pm 0.02$ & $0.09 \pm 0.06$ & $0.11 \pm 0.7$ & & $1.54 \pm 2.26$ & & $0.94 \pm$ \\
\hline $\mathrm{PO}_{4}{ }^{3-}-\mathrm{P}(\mu \mathrm{g} / \mathrm{L})$ & $\begin{array}{r}9 . \\
1\end{array}$ & $\begin{array}{c}11.21 \pm \\
15.41\end{array}$ & $0.66 \pm 0.69$ & $0.36 \pm 0.26$ & $\begin{array}{r}103 \\
6\end{array}$ & $\begin{array}{r}45.8 \\
6.3\end{array}$ & $8.15 \pm 5.20$ & $6.67 \pm 3.98$ \\
\hline TSS (mg/L) & $\begin{array}{c}17.17 \pm \\
3.22\end{array}$ & $\begin{array}{c}26.50 \pm \\
4.22\end{array}$ & $\begin{array}{l}50.12 \pm \\
12.55\end{array}$ & $\begin{array}{c}40.54 \pm \\
3.14\end{array}$ & $\begin{array}{r}49 . \\
11\end{array}$ & $\begin{array}{c}104.75 \pm \\
156.45\end{array}$ & $30.25 \pm 9.61$ & \\
\hline Chl $a(\mu \mathrm{g} / \mathrm{L})$ & $\begin{array}{r}15.1 \\
1.8\end{array}$ & $\begin{array}{l}14.26 \pm \\
1.95\end{array}$ & $\begin{array}{r}68.6 \\
109 .\end{array}$ & $\begin{array}{c}30.80 \pm \\
28.03\end{array}$ & $\begin{array}{c}47.11 \pm \\
9.13\end{array}$ & $\begin{array}{c}121.52 \pm \\
101.80\end{array}$ & $11.69 \pm 5.66$ & $\begin{array}{c}32.80 \pm \\
27.10\end{array}$ \\
\hline $\begin{array}{r}\mathrm{Cl} \\
\text { densi }\end{array}$ & $3.90 \pm 2.53$ & $2.47 \pm 1.94$ & $\begin{array}{c}255.40 \pm \\
90.01\end{array}$ & $\begin{array}{c}85.68 \pm \\
69.04\end{array}$ & $\begin{array}{c}32.40 \pm \\
44.93\end{array}$ & $7.82 \pm 7.26$ & $54.37 \pm 27.72$ & $\begin{array}{c}30.72 \pm \\
38.09\end{array}$ \\
\hline $\begin{array}{l}\text { Copepoda } \\
\text { abundance } \\
\text { (ind./L) }\end{array}$ & $2.98 \pm 0.84$ & $6.07 \pm 6.64$ & $\begin{array}{c}20.70 \pm \\
8.42\end{array}$ & $\begin{array}{c}26.67 \pm \\
18.40\end{array}$ & $\begin{array}{c}62.02 \pm \\
61.83\end{array}$ & $\begin{array}{c}49.50 \pm \\
42.96\end{array}$ & $33.90 \pm 11.64$ & $9.37 \pm 6.80$ \\
\hline $\begin{array}{l}\text { Rotifera } \\
\text { abundance } \\
\text { (ind./L) }\end{array}$ & $\begin{array}{c}3012.50 \pm \\
837.07\end{array}$ & $\begin{array}{c}2575.00 \pm \\
803.27\end{array}$ & $\begin{array}{c}90.00 \pm \\
59.67\end{array}$ & $\begin{array}{c}55.00 \pm \\
43.59\end{array}$ & $\begin{array}{c}149.17 \pm \\
67.71\end{array}$ & $\begin{array}{c}119.17 \pm \\
75.66\end{array}$ & $17.50 \pm 14.05$ & $\begin{array}{l}5.00 \pm \\
12.25\end{array}$ \\
\hline $\begin{array}{c}\text { Zooplankton } \\
\text { biomass }(\mu \mathrm{g} / \mathrm{L})\end{array}$ & $\begin{array}{c}4703.43 \pm \\
1960.17\end{array}$ & $\begin{array}{c}3835.63 \pm \\
1589.72\end{array}$ & $\begin{array}{c}5774.12 \pm \\
5183.55\end{array}$ & $\begin{array}{c}208.88 \pm \\
174.98\end{array}$ & $\begin{array}{c}118.95 \pm \\
88.77\end{array}$ & $\begin{array}{c}75.22 \pm \\
45.27\end{array}$ & $\begin{array}{c}200.88 \pm \\
46.90\end{array}$ & $\begin{array}{c}140.35 \pm \\
117.77\end{array}$ \\
\hline $\begin{array}{c}\text { phytoplankton } \\
\text { biomass } \\
\text { (cells/L) }\end{array}$ & $\begin{array}{c}1.06 \times 10^{6} \pm \\
4.61 \times 10^{5}\end{array}$ & $\begin{array}{c}9.17 \times 10^{5} \pm \\
3.26 \times 10^{5}\end{array}$ & $\begin{array}{c}1.41 \times 10^{8} \pm \\
2.62 \times 10^{5}\end{array}$ & $\begin{array}{c}2.52 \times 10^{7} \pm \\
3.26 \times 10^{7}\end{array}$ & $\begin{array}{c}9.66 \times 10^{7} \pm \\
8.26 \times 10^{7}\end{array}$ & $\begin{array}{c}6.81 \times 10^{8} \pm \\
1.49 \times 10^{9}\end{array}$ & $\begin{array}{c}1.57 \times 10^{8} \pm \\
7.06 \times 10^{7}\end{array}$ & $\begin{array}{c}1.27 \times 10^{9} \pm \\
1.59 \times 10^{9}\end{array}$ \\
\hline
\end{tabular}

* Corresponding author: zhaoby@ujs.edu.cn 

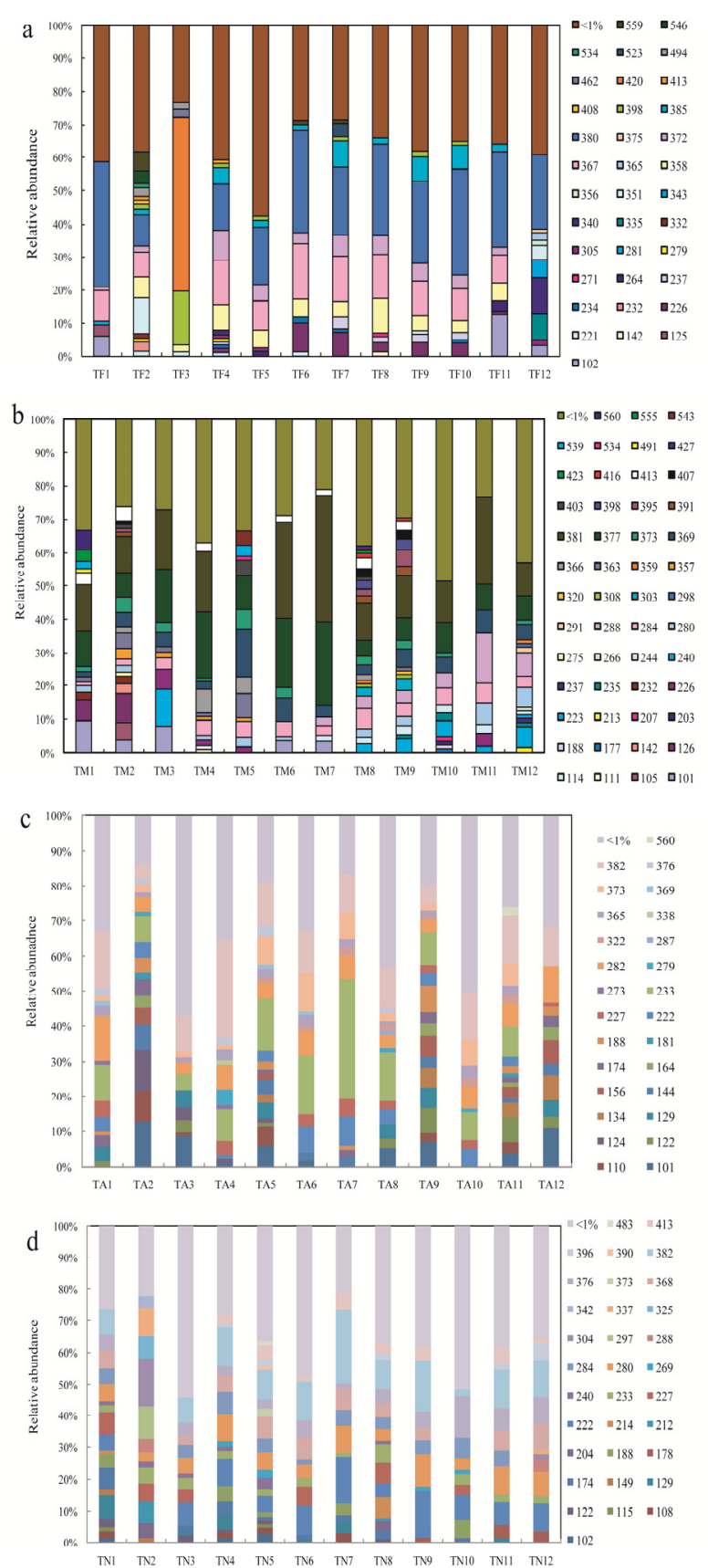

Fig. 2 Relative abundance of microbial eukaryotic 18S rRNA gene amplicons based on T-RFLP analysis after restriction with $M s p$ I. Numbers in the legend indicate the length of T-RFs in base pairs (bp). T-RFs having relative gene frequencies $<1 \%$ were grouped together and indicated as ' $<1 \%$ '. a. February, b. May, c. August, d. November.

\subsection{T-RFLP analysis}

The samples in winter (February) were much different from other seasons. No T-RFs were shared by all the samples in February, while T-RFs at 284, 369 and 377 bp in length were detected in all samples in May, T-RFs at 282 and 382 bp in length in all samples in August, and T-RFs at $280 \mathrm{bp}$ in length in all samples in November. The most abundant T-RF was 380/381/382 in all the seasons, and it was fewest in the site 2 in summer and autumn (TA2 and TN2), while TF3 and TM5 in winter and spring, respectively (Fig. 2).
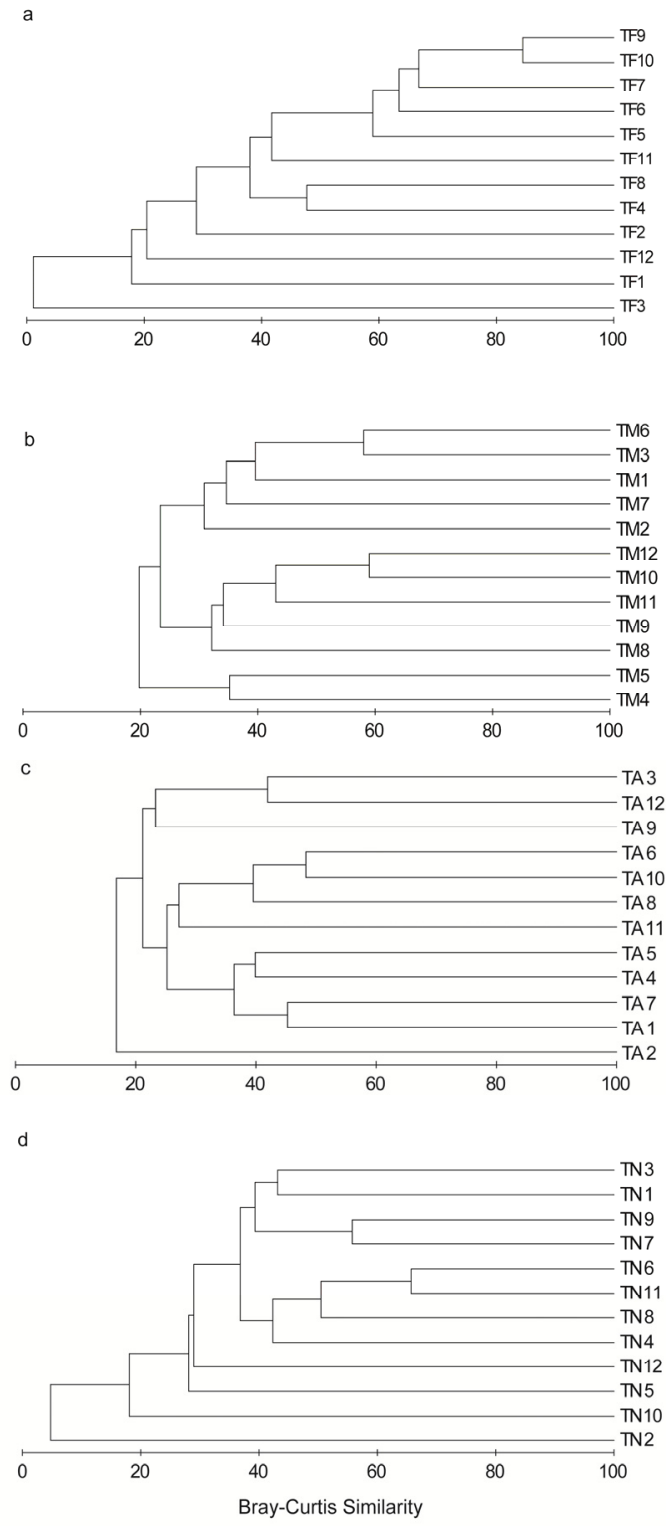

Fig. 3 Cluster analysis of samples based on T-RFLP analysis. a. February, b. May, c. August, d. November

The Bray-curtis similarity showed that all the 12 samples in February had the lowest similarity. TF3 was separated with other samples, while TF5, TF6, TF7, TF9 and TF 10 were were clustered together, their similarity was $60 \%$ nearly. In this group, TF9 and TF 10 had the highest similarity (more than $80 \%$ ). All the samples in May had the highest similarity (nearly 20\%). TM1-7 were clusterd into one group which had the lower similarity, while TM8-12 were in one group had the higher similarity (more than 30\%). TA2 which was a single branch in August had a low similarity with other samples (less than 20\%). The samples in pelagic zone (eg. TA1, TA4, TA5 and TA7 were gathered together, and the similarity was is close to $40 \%$ ). TN2 which was similar with TA2 had a low similarity with other samples in November (less than 10\%). The samples except TN2 
and TN10 were in one group (the similarity was is close to $30 \%$ ) (Fig. 3).

\subsection{Effects of environmental factors on microbial eukaryotic community}

The CCA model showed that the concentration of DO, water temperature, and the concerntration of TP contributed most of the microbial eukaryotic community composition in February (for all canonical axes, $p<0.05$, Fig. $4 a$ ). The percentage of cumulative variance of the first two axes was $40.59 \%$, and $64.21 \%$ were explained by all four axes.

Depth, TSS, DO, temperature, $\mathrm{pH}$, and zooplankton biomass were the most important factors explaining the variability of T-RFLP profiles in May (for all canonical axes, $\mathrm{p}<0.05$; Fig. 4b). The first 2 axes explained $29.22 \%$ of the observed variations in the composition of microbial eukaryotic communities, and all 4 canonical axes explained $49.09 \%$ of the observed variation.

$\mathrm{DO}$, depth, $\mathrm{pH}$, temperature, and phytoplankton biomass contributed most of the microbial eukaryotic community composition in August (for all canonical axes, $p<0.05$, Fig. $4 \mathrm{c}$ ). The percentage of cumulative variance of the first two axes was $26.39 \%$, and $44.16 \%$ were explained by all four axes.

The results of CCA illustrated that the phytoplankton biomass, temperature, TSS, and SD were the most important factors explained the variability of T-RFLP profiles of microbial eukaryote in November (Fig. 4d). The percentage of cumulative variance of the first two axes was $21.46 \%$, and $35.10 \%$ were explained by all four axes.

Thus, among bottom-up factors, the trophic status appeared to control significantly the microbial eukaryotic community composition in all the seasons; while zooplankton biomass which is a top-down regulation factor, seemed to be the main factor associated with variations in microbial eukaryotic community composition in May [25].
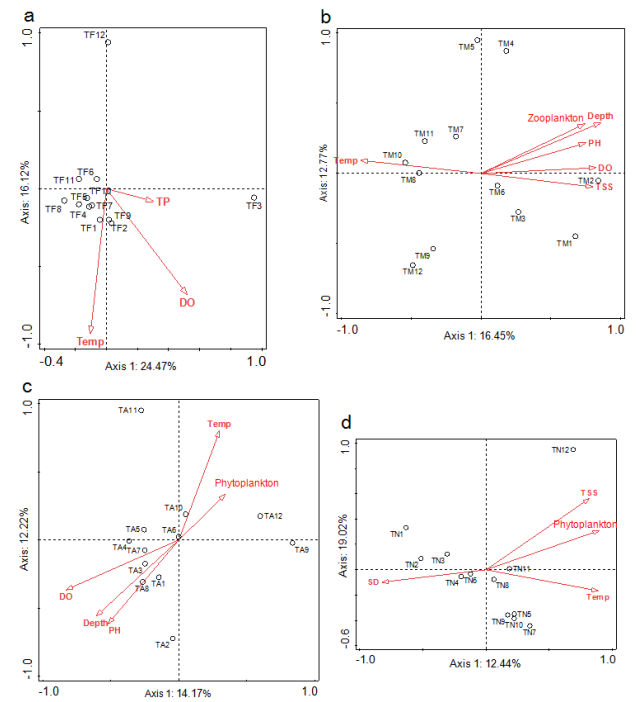

Fig. 4 CCA biplots showing the microbial eukaryotic communities in relation to the important environmental factors. a. February, b. May, c. August, d. November.

\section{Discussion}

The objective of this study was to investigate the genetic diversity of microbial eukaryotes in the pelagic and littoral zones of Lake Taihu, and to identify the environment factors in relation to microbial eukaryotic community composition variability. A culture-independent methods - T-RFLP was used to analyze the microbial eukaryotes. T-RFLP has been successfully to identify bacteria [26] and microbial eukaryotes [14]. The result of T-RFLP indicated that microbial eukaryotes were distinct in different zone. This phenomenon was supported by the previous study [27].

The community compositions of microbial eukaryotes were related to the temporal variations of physical, chemical and biological parameters [2, 10-15]. In the present study, the microbial community compositions in each season were related with the trophic status. The CCA models suggested that the composition of microbial eukaryotes were significantly affected by DO and water temperature in the whole year except November $(p<0.05)$, while depth and $\mathrm{pH}$ had a significant influence on the microbial eukaryotes in warmer seasons $(p<0.05$, May and August). Meiliang Bay is an eutrophic zone with cyanobacterial blooms regularly in summer [28]. Cyanobacterial blooms can influence heterotrophic bacteria and surrounding environments and then affect the heterotrophic protists $[29,30]$. DO was negatively correlated with Chl $a(p<$ 0.05 ) in summer when cyanobacteria outbreak occured in warmer seasons (May and August), and it indicated that the variation of chemical parameters mainly depend on cyanobacteria. Furthermore, because dense Microcystis can remove oxygen through normal respiration at night or the alga decomposition process [31], oxygen in water was not enough to support other plankton in the vicinity [32]. Oxygenation played a vital role in changes of genetic diversity microbial eukarytoes. The study of the mesocosm experiment found that temporal changes in microbial eukaryotic communities mianly depend on the changes in $\mathrm{pH}$ and the concentrations of dissolved oxygen induced by the addition of Microcystis spp. [33].

The CCA analysis of the samples in February showed that the concentration of TP was highly correlated with microbial eukaryotes, which was attributed to the changes of nitrogen nutrients [34]. Lepère et al. found that the nutrient levels had a significant impact on small eukaryotic communities [14]. In additional, the nutrients were one of the bottom-up factors that seemed to be the main factor associated with variations in small eukaryotic communities in the photic zone [34]. With reference to bottum-up regulation, picophytoplanktons are characterized as a high surface/volume ratio with a large surface for exchange, which favours nutrient uptake [34]. The previous studies suggested that the contribution of picophytoplankton to total phytoplankton biomass decreased with the increase of trophic status [35]. Therefore, the regulation of phytoplankton biomass on the variations of microbial eukaryotes depends on trophic status. 
TSS, the indicator of sediment resuspension exhibited, was the most important factor explaining the variability of T-RFLP profiles in May and November. Sediment resuspension is one of the important characteristics of Lake Taihu [36]. Meiliang Bay is prone to wind-driven sediment resuspension indicated by the concentration of TSS [37]. The wind-induced sediment resuspension which occurred with reduction of light penetration, increase of nutrient availability, and reduction of cell sedimentation losses could affect the phytoplanktons [38], and then changed the genetic diversity of microbial eukaryotes.

Many studies have revealed that predation by metazooplankton played an important role in structuring the microbial food web [12]. The CCA model indicated the variations of microbial eukaryotic community compositions from the pelagic to littoral zone in November were linked to zooplankton biomass, confirming that microbial eukaryote community structures were partially linked to the abundance of metazooplankton $[11,13]$. Lepère et al. revealed that small eukaryotes were exposed mainly to the predation of rotifers and small cladocerans (Bosminidae, Chydoridae) [34]. The favourite food size of filtering cladocerans was less than $40-50 \mu \mathrm{m}$, and the cladocerans could exert a pronounced effect on the whole protist community and the whole microbial food web, including ciliates, larger bacteria, and picoalgea [39, 40]. The food size of copepoda was larger than cladocera, and copepoda are known to be the efficient selective grazers of larger planktonic ciliates [39] and are probably of minor importance as grazers of nanoplankton [41]. The large bacteria, heterotrophic flagellates and small ciliates were the food of $10 \%-40 \%$ rotifers [42]. Futhermore, rotifers would be the efficient predators on protozoans according to experiments regarding food selection [42].

\section{Conclusion}

In this study, the genetic diversity of microbial eukaryotes were investigated in the pelagic and littoral zones of Meiliang Bay of Lake Taihu. The T-RFLP analysis demonstrated that the microbial eukaryotic community compositions differed between the pelagic and littoral zones. However, the difference decreased in warm temperature. Multivariate statistical analysis suggested that bottom-up affected microbial eukaryotes in all the seasons, while top-down by zooplanktons was only found in summer.

Acknowledgments We are grateful for useful comments and suggestions by two anonymous reviewers. This work was funded by the National Natural Science Foundation of China (No. 31800386) and Chinese Postdoctoral Science Found (No. 2019M651721).

\section{References}

1. F. Chen, M. Chen, F. Kong, X. Wu, Q.L Wu. Species-dependent effects of crustacean plankton on a microbial community, assessed using an enclosure experiment in Lake Taihu, China. Limnol Oceanogr 57: 1711-1720 (2012)

2. W. Zhang, Y. Pan, L. Yu, L. Liu, Genetic diversity patterns of microeukaryotic plankton communities in Shenhu Bay, southeast China. Cont Shelf Res 141: 68-75 (2017)

3. L. Jardillier, M.V. Zubkov, J. Pearman, D.J. Scanlan, Significant $\mathrm{CO} 2$ fixation by small prymnesiophytes in the subtropical and tropical northeast Atlantic Ocean. The ISME journal 4: 1180-1192 (2010)

4. R. Simó, Production of atmospheric sulfur by oceanic plankton: biogeochemical, ecological and evolutionary links. Trends Ecol Evol 16: 287-294 (2001)

5. J. Sun, Z. Yu, Y. Gao, Q. Zhou, Y. Zhen, H. Chen, L. Zhao, Q. Yao, T. Mi, Phytoplankton diversity in the East China Sea and Yellow Sea measured by PCR-DGGE and its relationships with environmental factors. Chin J Oceanol Limnol 28: 315-3222 (2010)

6. H. Lv, J. Yang, L. Liu, Temporal pattern prevails over spatial variability in phytoplankton communities from a subtropical water supply reservoir. Oceanol Hydrobiol Stud 42: 420-430 (2013)

7. H.M. Bik, D.L. Porazinska, S. Creer, J.G. Caporaso, R. Knight, W.K. Thomas, Sequencing our way towards understanding global eukaryotic biodiversity. Trends Ecol Evol 27: 233-243 (2012)

8. P. López-García, F. Rodriguez-Valera, C. Pedros-Alio, D. Moreira, Unexpected diversity of small eukaryotes in deep-sea Antarctic plankton. Nature 409: 603-607 (2001)

9. J. Šlapeta, D. Moreira, P. López-García, The extent of protist diversity: insights from molecular ecology of freshwater eukaryotes. Proc R Soc B 272: 2073-2081 (2005)

10. M. Chen, F. Chen, B. Zhao, Q. WU, F. Kong, Spatio-temporal variability of microbial eukaryotic community composition in a large shallow subtropical lake, assessed by $18 \mathrm{~S}$ rRNA gene sequences. Acta Protozool 48: 245-264(2009)

11. T. Garstecki, R. Verhoeven, S.A. Wickham, H. Arndt, Benthic-pelagic coupling: a comparison of the community structure of benthic and planktonic heterotrophic protists in shallow inlets of the southern Baltic. Freshw Biol 45: 147-167 (2000)

12. K. Jürgens, E. Jeppesen, The impact of metazooplankton on the structure of the microbial food web in a shallow, hypertrophic lake. J Plankton Res 22: 1047-1070 (2000)

13. M. Lefranc, A. Thénot, C. Lepère, D. Debroas, Genetic diversity of small eukaryotes in lakes differing by their trophic status. Appl Environ Microbiol 71: 5935-5942 (2005) 
14. C. Lepère, D. Boucher, L. Jardillier, I. Domaizon, D. Debroas, Succession and regulation factors of small eukaryote community composition in a lacustrine ecosystem (Lake Pavin). Appl Environ Microbiol 72: 2971-2981 (2006)

15. M. Simon, H.P. Grossart, B. Schweitzer, H. Ploug, Microbial ecology of organic aggregates in aquatic ecosystems. Aquat Microb Ecol 28: 175-211 (2002)

16. M. Chen, F. Chen, B. Zhao, Q.L. Wu, F. Kong, Seasonal variation of microbial eukaryotic community composition in the large, shallow, subtropical Taihu Lake, China. Aquat Ecol 44: 1-12 (2010)

17. Y. Chen, B. Qin, K. Teubner, M. Dockulil, Long-term dynamics of phytoplankton assemblages: Microcystis-domination in Lake Taihu, a large shallow lake in China. J Plankton Res 25: 445-453 (2003)

18. M. Chen, F. Chen, Y. Yu, J. Ji, F. Kong, Genetic diversity of eukaryotic microorganisms in Lake Taihu, a large shallow subtropical lake in China. Microb Ecol 56: 572-583 (2008)

19. X. Jin, Q. Tu, The standard methods for observation and analysis in lake eutrophication, 2nd edn. Chinese Environ mental Science Press, Beijing: pp:138-272(in Chinese) (1990)

20. R.J. Gast, M.R. Dennett, D.A. Caron, Characterization of protistan assemblages in the Ross Sea, Antarctica, by denaturing gradient gel electrophoresis. Appl Environ Microbiol 70: 2028-2037 (2004)

21. B. Díez, C. Pedrós-Alió, R. Massana, Study of genetic diversity of eukaryotic picoplankton in different oceanic regions by small-subunit rRNA gene cloning and sequencing. Appl Environ Microbiol 67: 2932-2941 (2001)

22. M. Ergert, M.W. Friedrich, Formation of pseudo-terminal restriction fragments, a PCR-related bias affecting terminal restriction fragment length polymorphism analysis of microbial community structure. Appl Environ Microb 69: 2555-2562 (2003)

23. K. Muylaert, G.K. Van-der, N. Vloemans, L.D. Meester, M. Gillis, W. Vyverman, Relationship between bacterial community composition and bottom-up versus top-down variables in four eutrophic shallow lakes. Appl Environ Microbiol 68: 4740-4750 (2002)

24. C. ter Braak, P. Šmilauer, Canoco Reference Manual and User's Guide: Software for Ordination (version 5.0). (Microcomputer power, Itaca, www. canoco. com), p. 496. (2012)

25. T. Weisse, H. Mueller, R.M. Pinto-coelho, A. Schweizer, D. Springmann, G. Baldringer, Response of the microbial loop to the phytoplankton spring bloom in a large prealpine lake. Limnol Oceanogr 35: 781-794 (1990)
26. W.-T. Liu, T.L. Marsh, H. Cheng, L.J. Forney, Characterization of microbial diversity by determining terminal-restriction fragment length polymorphisms of genes encoding 16S rRNA. Appl Environ Microb 63: 4516-4522 (1997)

27. B. Zhao, M. Chen, Y. Sun, F. Chen, J. Yang, Genetic diversity of eukaryotic picoplankton of eight lakes in Nanjing (in Chinese). Environ Sci 31: 174-179 (2010)

28. B. Qin, W. Hu, G. Gao, L. Luo, J. Zhang, Dynamics of sediment resuspension and the conceptual schema of nutrient release in the large shallow Lake Taihu, China. Chinese Sci Bul 49: 54-64 (2004)

29. J.R. Seymour, S.A. Amin, J.-B. Raina, R. Stocker, Zooming in on the phycosphere: the ecological interface for phytoplankton-bacteria relationships. Nat Microbiol 2: 17065 (2017)

30. M. Haraldsson, M. Gerphagnon, P. Bazin, J. Colombet, S. Tecchio, T. Sime-Ngando, N. Niquil, Microbial parasites make cyanobacteria blooms less of a trophic dead end than commonly assumed. The ISME journal 12: 1008-1020 (2018)

31. D.R.d. Figueiredo, A.S.S.P. Reboleira, S.C. Antunes, N. Abrantes, U. Azeiteiro, F. Gonçalves, M.J. Pereira1, The effect of environmental parameters and cyanobacterial blooms on phytoplankton dynamics of a Portuguese temperate lake. Hydrobiologia 568: 145-157 (2006)

32. B.L. Jones, Lake Okeechobee eutrophication research and management. Aquatics 9: 21-26 (1987)

33. M. Chen, F. Chen, P. Xing, H. Li, Q.L. Wu, Microbial eukaryotic community in response to Microcystis spp. bloom, as assessed byan enclosure experiment inLakeTaihu,China. FEMS Microbiol Ecol 74: 19-31 (2010)

34. C. Lepère, I. Domaizon, D. Debroas, Community composition of lacustrine small eukaryotes in hyper-eutrophic conditions in relation to top-down and bottom-up factors. FEMS Microbiol Ecol 61: 483-495 (2007)

35. T. Bell, J. Kalff, The contribution of picophytoplankton in marine and freshwater systems of different trophic status and depth. Limnol Oceanogr 46: 1243-1248 (2001)

36. W. Chen, Y. Chen, X. Gao, I. Yoshida, Eutrophication of Taihu and its control. Agr Eng J 6: 106-120 (1997)

37. X. Song, Z. Liu, G. Yang, Y. Chen, Effects of resuspension and eutrophication level on summer phytoplankton dynamics in two hypertrophic areas of Lake Taihu, China. Aquat Ecol 44: 41-54 (2010)

38. M. Schallenberg, C.W. Burns, Effects of sediment resuspension on phytoplankton production: teasing apart the influences of light, nutrients and algal entrainment. Freshw Biol 49: 143-159 (2004)

39. B. Auer, H. Arndt, A study of changes between years in the structure of plankton community in taxonomic composition and biomass of 
heterotrophic flagellates in relation to lake trophy and season. Freshw Biol 46: 959-972 (2001)

40. U. Gaedke, A. Seifried, R. Adrian, Biomass size spectra and plankton diversity in a shallow eutrophic lake. Int Rev Hydrobiol 89: 1-20(2004)

41. K. Jürgens, G. Stolpe, Seasonal dynamics of crustacean zooplankton, heterotrophic nanoflagellates and bacteria in a shallow, eutrophic lake. Freshw Biol 33: 27-38 (1995)

42. H. Arndt, Rotifers as predators on components of the microbial web (bacteria, heterotrophic flagellates, ciliates) - a review. Hydrobiologia 255: 231-246 (1993) 